\title{
Influence of pH on the cytotoxic activity of inositol hexakisphosphate (IP6) in prostate cancer
}

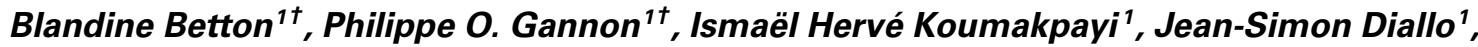 Anne-Marie Mes-Masson ${ }^{1,2}$ and Fred Saad ${ }^{1,3 *}$}

\author{
${ }^{1}$ Centre de Recherche du Centre Hospitalier de I'Université de Montréal and Institut du Cancer de Montréal, Montreal, OC, Canada \\ 2 Department of Medicine, Université de Montréal, Montreal, QC, Canada \\ ${ }^{3}$ Department of Surgery, Centre Hospitalier de I'Université de Montréal, Université de Montréal, Montreal, QC, Canada
}

\section{Edited by:}

Jerry Edward Chipuk, Mount Sinai

School of Medicine, USA

\section{Reviewed by:}

Gavin Mc Stay, Columbia University, USA

Paulo J. Oliveira, Center for Neuroscience and Cell Biology, Portugal

\section{${ }^{*}$ Correspondence:}

Fred Saad, Department of Surgery,

Hôpital Notre-Dame, 1560

Sherbrooke East, Montreal, QC,

Canada H2L 4M1.

e-mail: fred.saad@umontreal.ca

${ }^{\dagger}$ Blandine Betton and

Philippe O. Gannon have contributed

equally to this work.

\begin{abstract}
Objectives: In the present study, we investigated whether the $\mathrm{pH}$ of IP6 could influence its anti-tumoral activity in vitro. Methods: PC-3 cells were exposed to IP6 at pH 5, pH 7, and pH 12 and we evaluated the metabolic activity (WST-1 assay), cell proliferation (cell count), cell cycle distribution (FACS), and mitochondrial depolarization (JC-1 staining) in vitro. Results: Our results demonstrated that IP6 at $\mathrm{pH} 5$ and $\mathrm{pH} 12$ were more potent at lowering the metabolic activity of PC-3 cells than IP6 at pH 7. Treatment with IP6 at pH 12 also caused the greatest inhibition in cellular proliferation and accumulation of PC-3 cells in sub-G1. Finally, IP6 at pH 12 lead to a reduction in phospho-AKT and phospho-PDK1 and upregulated phospho-ERK. Conclusion: Together, our data strongly suggest that the $\mathrm{pH}$ of IP6 effectively modulates its anti-tumoral activity and should be reported in future studies.
\end{abstract}

Keywords: cell cycle, inositol hexakisphosphate (IP6), metabolic activity, PC-3 cells, phytochemicals

\section{INTRODUCTION}

Inositol hexakisphosphate (IP6) is a phytochemical that exhibits promising anti-tumoral properties against several mouse, rat, and human cancer cell lines including prostate cancer cells (Vucenik and Shamsuddin, 2006). IP6 is present in most cereals, legumes, nuts, oil seed, and soybean (Shamsuddin et al., 1997; Jariwalla, 2001) and is available as an over-the-counter dietary supplement without any reported toxicity or adverse reactions (Vucenik and Shamsuddin, 2003).

Effects on tumor cell proliferation, survival, and angiogenesis, were documented as being key anti-tumoral properties of IP6 against prostate cancer cells. Initial studies in PC-3 cells demonstrated that IP6 inhibits the growth and promotes the differentiation of PC-3 cells (Shamsuddin and Yang, 1995). Both hormone-sensitive (LNCaP) and hormone-refractory (Du145) cells are sensitive to G1 cell cycle arrest and apoptosis caused by IP6 (Singh et al., 2003; Agarwal et al., 2004). Our group later showed that hormone-refractory prostate cancer cells (DU145 and PC-3 cells) were more sensitive to IP6 treatment than hormone-sensitive prostate cancer cells (LNCaP and 22rv1 cells; Diallo et al., 2006).

In prostate cancer mice models, IP6 has documented in vivo anti-tumoral activity (Raina et al., 2008; Gu et al., 2009). Athymic mice, whose drinking water was supplemented with IP6, exhibited reduced growth of DU145 xenografts, which was associated with diminished tumor cell proliferation, increased tumor cell apoptosis, and reduced angiogenesis (Singh et al., 2004). In transgenic adenocarcinoma of the mouse prostate (TRAMP) mice, IP6 supplementation causes the development of a smaller lower urogenital track (bladder, seminal vesicles, prostate), an increase incidence of prostate intraepithelial neoplasia (PIN; low-grade and highgrade), and a decreased incidence of adenocarcinoma (Raina et al., 2008).

In terms of intracellular signaling, IP6 affects several pathways. IP6 decreases phospho-AKT (S473) in DU145 cells (Jagadeesh and Banerjee, 2006). In PC-3 cells, where PI3K signaling is constitutively activated due to altered expression/functions of PTEN, IP6 reduces phosphorylation of PI3K p85 (Y458), 3phosphoinositide-dependent kinase 1 (PDK1; S241), AKT (S473 and T208), GSK3 $\alpha / \beta$ (S21 and S9), decreases ILK1, and cyclin D1 protein levels (Gu et al., 2009). Altogether, IP6 shows promising cytotoxic activity against hormone-refractory prostate cancer cells such as DU145 and PC-3.

As IP6 is generally administered orally through the diet, typically in drinking water, IP6 must be buffered to a neutral $\mathrm{pH}$ before ingestion. IP6 salts are commercially available in several forms, which when reconstituted in water result in widely different pH. Typical formulations of the IP6 salt are basic and when reconstituted in water result in a solution at $\mathrm{pH} 12$, which is not apt for consumption. The goal of this study was thus to validate whether the previously documented anti-tumoral properties of IP6 were modulated by the $\mathrm{pH}$. Our results demonstrate that IP6 at $\mathrm{pH} 12$ had different effects than IP6 solutions at $\mathrm{pH} 7$ or $\mathrm{pH} 5$. We conclude that the effect of $\mathrm{pH}$ should be carefully monitored when evaluating the cytotoxic and anti-cancer properties of IP6 and possibly other phytochemicals. 


\section{MATERIALS AND METHODS CELL CULTURE AND REAGENTS}

PC-3 and LNCaP cells were obtained from ATCC (Rockville, MD, USA). Myo-Inositol hexakisphosphate dodecasodium salt (IP6; US Biological, Swampscott, MA, USA) was diluted in water as a $100-\mathrm{mM}$ stock solution. The IP6 stock solution was at $\mathrm{pH}$ 12. The $\mathrm{pH}$ was adjusted to $\mathrm{pH} 5$ or $\mathrm{pH} 7$ by addition of $1 \mathrm{~N}$ hydrochloric acid $(\mathrm{HCl})$. It required 6.4 and $10.9 \mathrm{ml}$ of $1 \mathrm{~N} \mathrm{HCl}$ to buffer $100 \mathrm{ml}$ of $100 \mathrm{mM}$ IP6 pH 12 to $\mathrm{pH} 7$ and pH 5, respectively. Antibodies recognizing phospho-AKT (S473; cat\# 9271), phospho-PDK1 (S241; 3438) and phospho-ERK (T202/Y204; cat\# 9106L) were obtained from Cell Signaling (Danvers, MA, USA). Antibodies detecting PARP full-length (sc7150), PARP $85 \mathrm{kDa}$ (cat\# 9541), PARP $25 \mathrm{kDa}$ (cat\# 32064) were obtained from Santa Cruz Biotechnology (Santa Cruz, CA, USA), Cell Signaling and Abcam (Cambridge, MA, USA), respectively. The anti-Ran antibody (sc1146) and the horseradish peroxidase-conjugated secondary antibodies were obtained from Santa Cruz Biotechnology (Santa Cruz, CA, USA). The antibodies recognizing actin (ab-6278) and GAPDH (ab-9485) were obtained from Abcam (Cambridge, MA, USA).

\section{WST-1 METABOLIC ASSAY}

The WST-1 metabolic assay was done as previously described by our group (Diallo et al., 2006, 2008). Briefly, PC-3 cells were plated at 200,000 cells $/ \mathrm{ml}$ in 96-well plates in a final volume of $100 \mu \mathrm{l} /$ well. After a 24 -h incubation with $\mathrm{H}_{2} \mathrm{O}$ or IP6 at the various $\mathrm{pH}$ and at the indicated concentrations, $20 \mu \mathrm{l}$ of WST-1 reagent (Roche Diagnostics, Indianapolis, IN, USA) was added and the plates were incubated for $24 \mathrm{~h}$. WST-1 signal was measured at $450 \mathrm{~nm}$ with reference wavelength at $655 \mathrm{~nm}$.

\section{CELLULAR PROLIFERATION}

PC-3 cells were plated at 15,000 cells/ml in 6-well plates, allowed to adhere overnight and then treated with $2 \mathrm{mM}$ IP6 at $\mathrm{pH} 5$, $\mathrm{pH} 7$, or $\mathrm{pH} 12$ or the equivalent volumes of $\mathrm{pH}$-adjusted $\mathrm{H}_{2} \mathrm{O}$ controls over a period of $72 \mathrm{~h}$. At indicated times cells were trypsinized, combined with non-adherent cells and counted using a cell counter (Casy, Roche Innovatis, Germany).

\section{CELL CYCLE DISTRIBUTION ANALYSIS}

PC-3 cells were plated at 200,000 cells $/ \mathrm{ml}$ in 6 -well plates. PC-3 cells were exposed to $\mathrm{H}_{2} \mathrm{O}$ or $2 \mathrm{mM}$ IP6 at the various $\mathrm{pH}$ for 8 , 24,48 , and $72 \mathrm{~h}$. Adherent cells were trypsinized, combined with non-adherent cells, stained with propidium iodide (PI), and analyzed by flow cytometry. All experiments were repeated at least three times.

\section{WESTERN BLOT ANALYSIS}

Western blots were performed as previously described by our group (Diallo et al., 2006, 2008). Signal was developed with enhanced chemiluminescence (ECL) substrate (Amersham Life Sciences Inc., Arlington Heights, IL, USA).

\section{MITOCHONDRIAL DEPOLARIZATION ASSAY}

The mitochondrial assay was done as previously described by our group (Diallo et al., 2008). Briefly, PC-3 cells were plated at 200,000 cells $/ \mathrm{ml}$ in 6-well plates. PC-3 cells were incubated with a fluorescent cationic dye (JC-1 $10 \mu \mathrm{g} / \mathrm{ml})$ for $15 \mathrm{~min}$. Adherent cells were trypsinized, combined with non-adherent cells, and analyzed by flow cytometry. The fold change representing depolarized mitochondria (green-shift in JC-1 fluorescence) was calculated relative to mock-treated control.

\section{STATISTICAL ANALYSES}

Data are expressed as mean \pm SD. Comparisons between the IP6 or $\mathrm{H}_{2} \mathrm{O}$ controls at the various $\mathrm{pH}$ were performed using one-way ANOVA followed by post hoc Tukey tests. Statistical analyses were performed using SPSS version 16.0 (SPSS, Inc., Chicago, IL, USA). For all statistical analyses, $P$ values $<0.05$ were considered to be statistically significant.

\section{RESULTS}

\section{IP6 DIMINISHES THE METABOLIC ACTIVITY OF PC-3 CELLS}

We first evaluated the effect of the pH of IP6 on the metabolic activity of PC-3 cells. The cells were treated with either increasing doses of IP6 at pH 5, pH 7, and $\mathrm{pH} 12$ or the corresponding volumes of $\mathrm{H}_{2} \mathrm{O}$ also at $\mathrm{pH} 5, \mathrm{pH} 7$, and $\mathrm{pH} 12$. IP6 at pH $5(2.5,4$, and $5 \mathrm{mM}$ ) and $\mathrm{pH} 12$ (4 and $5 \mathrm{mM}$ ) induced a statistically significant reduction in the metabolic activity of PC-3 cells (Figure 1A) compared to the buffered $\mathrm{H}_{2} \mathrm{O}$ (Figure 1B; $P<0.05$, ANOVA). Statistically significant differences compared to the $\mathrm{H}_{2} \mathrm{O}$ controls were not observed with IP6 at pH 7, independently of the concentration tested. With regards to $\mathrm{pH}$, the IP6 at $\mathrm{pH} 12$ and at $\mathrm{pH} 5$ had the strongest inhibitory potential. At the highest doses tested, IP6 at $\mathrm{pH} 5$ reduced the metabolic rate by $88.0 \%(P<0.001$, compared to $\mathrm{H}_{2} \mathrm{O}$ at $\mathrm{pH} 5$, ANOVA), and, at similar concentration, IP6 at $\mathrm{pH} 12$ decreased the metabolic rate by $78.6 \%(P<0.001$, compared to $\mathrm{H}_{2} \mathrm{O}$ at $\mathrm{pH} 12$, ANOVA). Comparatively, the highest dose of IP6 solution at $\mathrm{pH} 7$ only reduced the metabolic activity by $26.1 \%\left(P=0.627\right.$, compared to $\mathrm{H}_{2} \mathrm{O}$ at $\mathrm{pH} 7$, ANOVA). Moreover, the lowest concentration at which IP6 at pH 5 and $\mathrm{pH} 12$ statistically significantly reduced the metabolic rate was $2.5 \mathrm{mM}$ ( $P=0.001$, compared to $\mathrm{H}_{2} \mathrm{O}$ at $\mathrm{pH} 5$ and $P=0.012$, compared to $\mathrm{H}_{2} \mathrm{O}$ at $\mathrm{pH} 12$, respectively, ANOVA).

We then evaluated the $\mathrm{IC}_{50}$ and $\mathrm{IC}_{75}$ for the various IP6 solutions. Due to the absence of a significant reduction in the metabolic activity following treatment with IP6 at $\mathrm{pH} 7$ no $\mathrm{IC}_{50}$ could be calculated. The $\mathrm{IC}_{50}$ for IP6 at $\mathrm{pH} 5$ was $2.39 \pm 0.19 \mathrm{mM}$ and $2.97 \pm 0.45$ for IP6 at $\mathrm{pH} 12$ (Table 1). Together, these results demonstrate that IP6 solutions at different $\mathrm{pH}$ have divergent effect on the metabolic activity of PC-3 cells.

Finally, we inquired whether the addition of small volumes $(60 \mu \mathrm{l})$ of IP6 or buffered $\mathrm{H}_{2} \mathrm{O}$ solutions could significantly change the $\mathrm{pH}$ of the culture media (Figure A1 in Appendix). Our analyses showed that, at time of administration $(t-0 \mathrm{~h})$ and compared to water controls, the IP6 at pH 12 and at pH 5 significantly modulated the $\mathrm{pH}$ of the culture media $(P<0.001$, ANOVA). These changes in $\mathrm{pH}$ were however absent after $24 \mathrm{~h}$ of treatment.

\section{IP6 AT pH 12 HAS THE STRONGEST ANTI-PROLIFERATION EFFECT ON PC-3 CELLS}

We next evaluated the impact of $\mathrm{pH}$ on the anti-proliferation action of IP6. As previously described, PC-3 cells were treated 


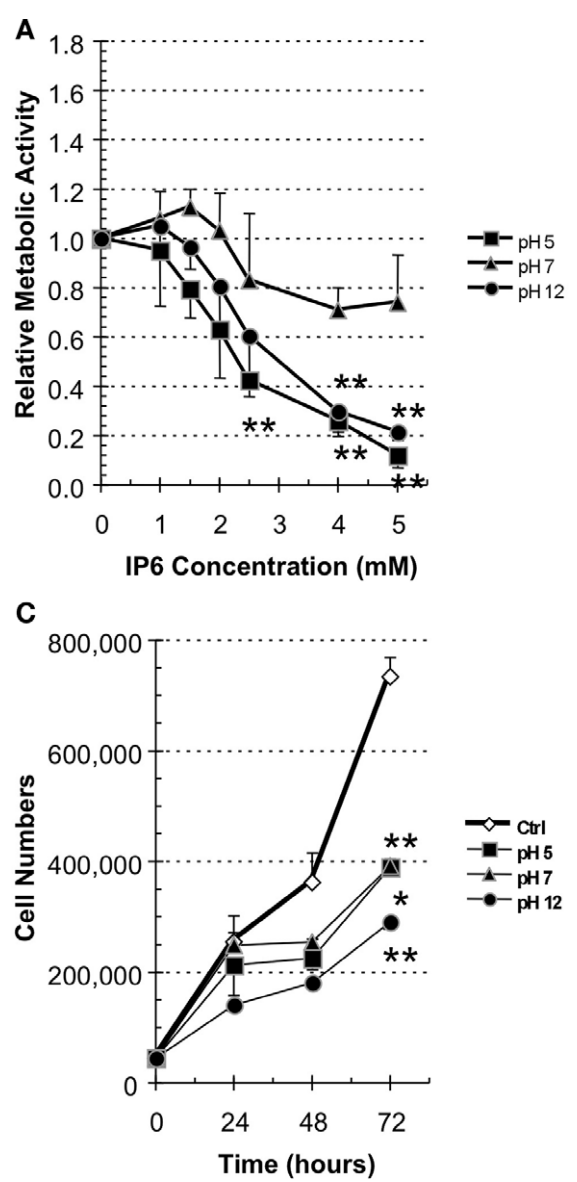

FIGURE 1 | IP6 decreases the metabolic activity and cellular proliferation of PC-3 cell lines. (A,B) PC-3 cells were treated for $24 \mathrm{~h}$ with increasing concentration of (A) IP6 at pH 5, pH 7, or pH 12 or (B) corresponding volume of $\mathrm{H}_{2} \mathrm{O}$ at pH 5, pH 7, or pH 12. Metabolic activity was measured using the WST-1 assay and calculated relative to controls. Data represents the average of three experiments done in triplicate. Errors bars represent standard error of the mean. Statistically significant differences
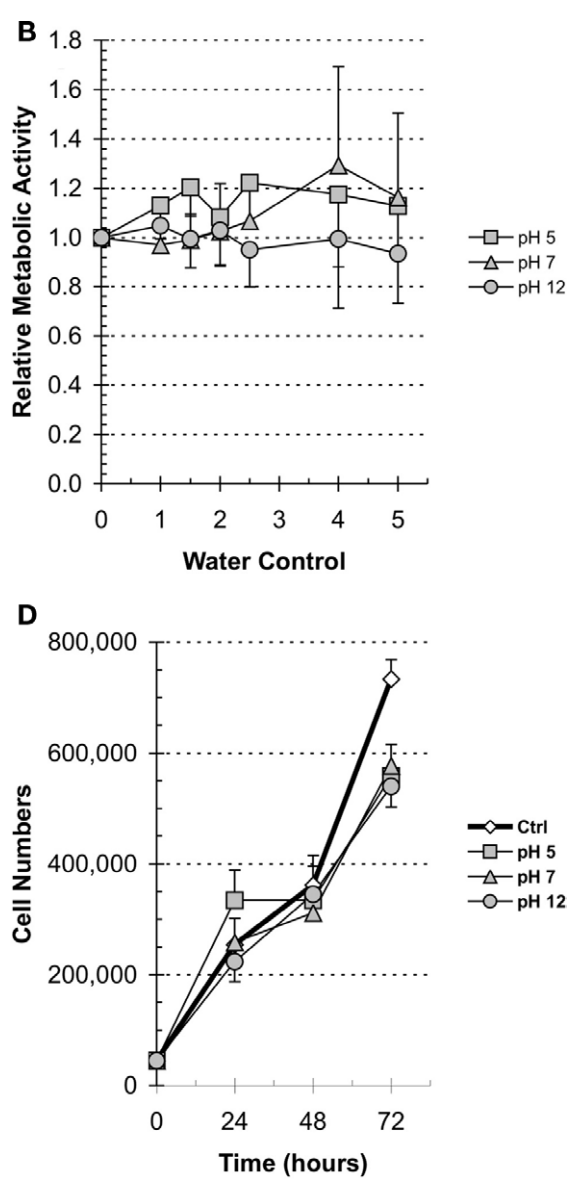

compared to the corresponding water control. (C,D) PC-3 cells were treated with (C) $2 \mathrm{mM} \mathrm{IP6}$ at pH 5, pH 7, or pH 12 or (D) the corresponding volumes of $\mathrm{H}_{2} \mathrm{O}$ at $\mathrm{pH} 5, \mathrm{pH}$, and $\mathrm{pH}$ 12. Cellular proliferation was examined by cell count at 24,48 , and $72 \mathrm{~h}$. Data represents average of three experiments. Errors bars represent standard error of the mean. Statistically significant differences compared to the corresponding water control where ${ }^{*} P<0.05$ and ${ }^{*} P<0.001$ (ANOVA). with $2 \mathrm{mM}$ IP6 solutions or with the corresponding volumes of buffered $\mathrm{H}_{2} \mathrm{O}$. We chose the 2-mM IP6 dose in line with other studies by our group (Diallo et al., 2008) and others (Gu et al., 2009; Roy et al., 2009). Following a 72-h stimulation, IP6 at pH 12 significantly reduced cell number by $60.4 \%$ ( $P=0.001$, compared to $\mathrm{H}_{2} \mathrm{O}$ at $\mathrm{pH} 12$, ANOVA), whereas a treatment with IP6 at pH 5 reduced the proliferation rate by $46.9 \%$ ( $P=0.0029$, compared to $\mathrm{H}_{2} \mathrm{O}$ at $\mathrm{pH} 5$, ANOVA), and by $46.6 \%$ for the IP6 at $\mathrm{pH}$ $7\left(P=0.015\right.$, compared to $\mathrm{H}_{2} \mathrm{O}$ at $\mathrm{pH}$ 7, ANOVA; Figures 1C,D). Together, these results suggest that IP6 at $\mathrm{pH} 12$ had the strongest anti-proliferation potential.

\section{IP6 AT pH 12 INCREASES THE PROPORTION OF SUB-G1 PC-3 CELLS}

We then assessed whether the reduction in metabolic activity and in cellular proliferation (Figure 1) was related to an increase in cell death. PC-3 cells were treated as previously described with either $2 \mathrm{mM} \mathrm{IP} 6$ or $\mathrm{H}_{2} \mathrm{O}$ controls over a period of $72 \mathrm{~h}$. Adherent and non-adherent cells were analyzed by FACS, following staining with PI for $15 \mathrm{~min}$. We observed that, compared to $\mathrm{H}_{2} \mathrm{O}$, only the
Table 1 | IC $\mathrm{C}_{50}$ and $\mathrm{IC}_{75}$ of IP6 at varying $\mathrm{pH}$.

\begin{tabular}{lll}
\hline & [] at $* \mathbf{I C}_{\mathbf{5 0}}$ & [] at $* \mathbf{I C}_{\mathbf{7 5}}$ \\
\hline IP6 pH 5 & $2.39 \pm 0.19$ & $3.96 \pm 0.60$ \\
IP6 pH 7 & $\mathrm{N} / \mathrm{A}$ & $\mathrm{N} / \mathrm{A}$ \\
IP6 pH 12 & $2.97 \pm 0.45$ & $4.04 \pm 0.64$
\end{tabular}

N/A, non-applicable.

${ }^{*}$ Concentration in millimolar.

IP6 solution at $\mathrm{pH} 12$ caused a statistically significant increase in sub-G1 cells at $8 \mathrm{~h}(5.21$ vs $0.71 \%, P<0.001$, ANOVA) and at $24 \mathrm{~h}$ ( 3.96 vs $0.59 \%, P<0.001$, ANOVA; Figure $2 \mathrm{~A}$ ). At $8 \mathrm{~h}$, the increase in sub-G1 cells was also associated with a decrease in PC-3 cells in G2/M phase (Table 2). No statistically significant induction of sub-G1 PC-3 cells were observed following treatment with IP6 at $\mathrm{pH} 5$ or at $\mathrm{pH} 7$ or with the corresponding $\mathrm{H}_{2} \mathrm{O}$ controls (Table A1 in Appendix). 


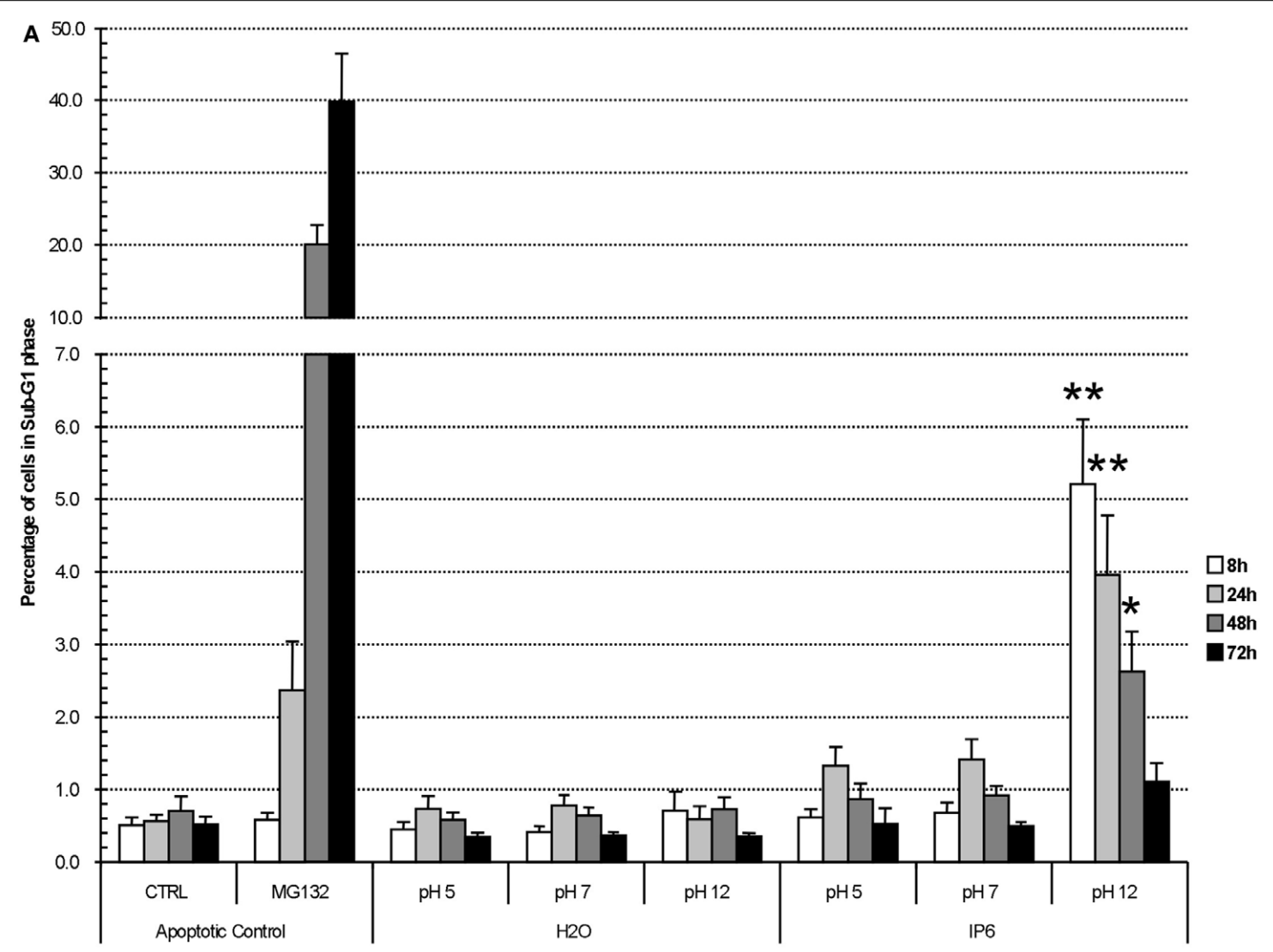

B

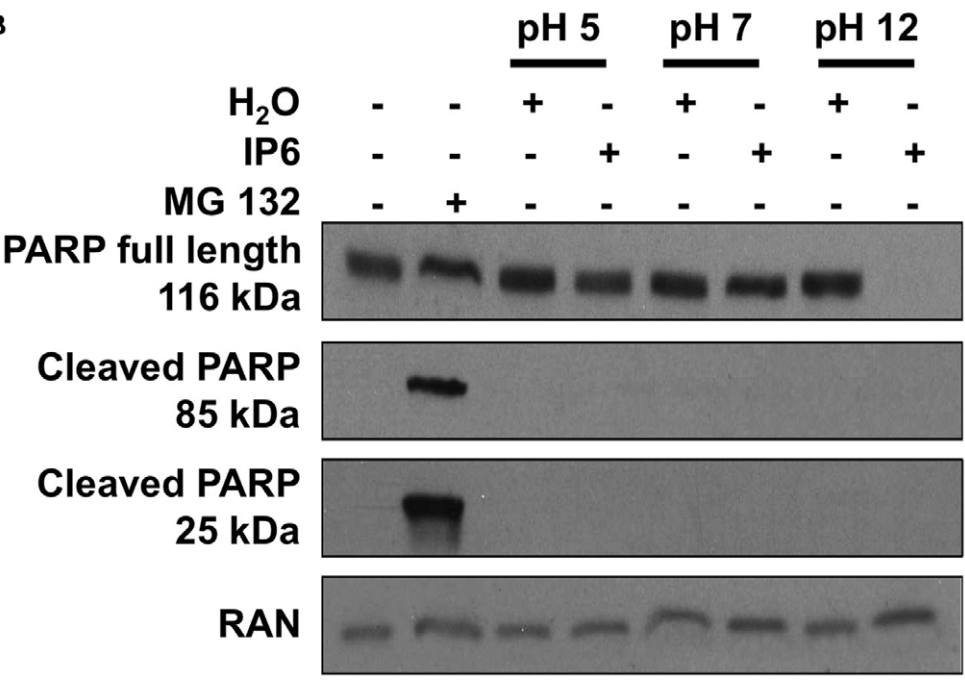

FIGURE 2 | IP6 at pH 12 leads to an increase in sub-G1 PC-3 cells. (A) PC-3 cells were stained with PI after a 24-h treatment with either $2 \mathrm{mM}$ IP6 at $\mathrm{pH} 5, \mathrm{pH} 7$, or $\mathrm{pH} 12$ or the corresponding volumes of $\mathrm{H}_{2} \mathrm{O}$ at $\mathrm{pH} 5, \mathrm{pH}$ 7, and $\mathrm{pH}$ 12. The percentage of cells in G1, S, G2/M, and sub-G1 phases was determined by FACS. MG132 served as a control to induce cellular apoptosis. Data is represented as the relative fold change compared to non-treated control. Average of three experiments done in triplicate. Errors bars represent standard error of the mean. (B) Whole-cell extracts were prepared following a 24-h treatment as previously described. Western blotting was used to probe for PARP and cleaved-PARP (85 and $25 \mathrm{kDa}$ ). RAN expression was used as a loading control. Blot is representative of three independent experiments.

\section{IP6 AT pH 12 MODULATES THE LEVEL OF PARP-1}

By Western blot, we then studied whether Poly (ADP-ribose) polymerase 1 (PARP-1), was cleaved following IP6 treatment, as an indication of apoptosis induction. Following a 24-h stimulation with $2 \mathrm{mM}$ IP6 at $\mathrm{pH} 12$, we observed a most complete disappearance of full-length PARP-1 (Figure 2B). Surprisingly, 
this reduction in PARP-1 expression was not associated with the appearance of the cleaved-PARP 85 and $25 \mathrm{kDa}$ fragments as observed with the MG132 positive control stimulation. We did not detect any reduced expression of full-length PARP-1 or PARP-1 cleavage following treatment with IP6 at pH 5 or at pH 7.

We also noticed that the effects observed by IP6 at different $\mathrm{pH}$ varied according to the cell line used in the experiment. Using the hormone-sensitive LNCaP cell line treated with the various IP6 solutions, we observed an elevated expression of the cleaved-PARP-1 $25 \mathrm{kDa}$ fragment following exposure to IP6, something that was not observed with the PC-3 cell line (Figure A2 in Appendix).

\section{IP6 DOES NOT CAUSE MITOCHONDRIAL DEPOLARIZATION}

The reduction in metabolic activity, cellular proliferation combined with the abundance of sub-G1 PC-3 cells lead us to

Table 2 | Cell cycle distribution* after $8 \mathrm{~h}$ of IP6 treatment.

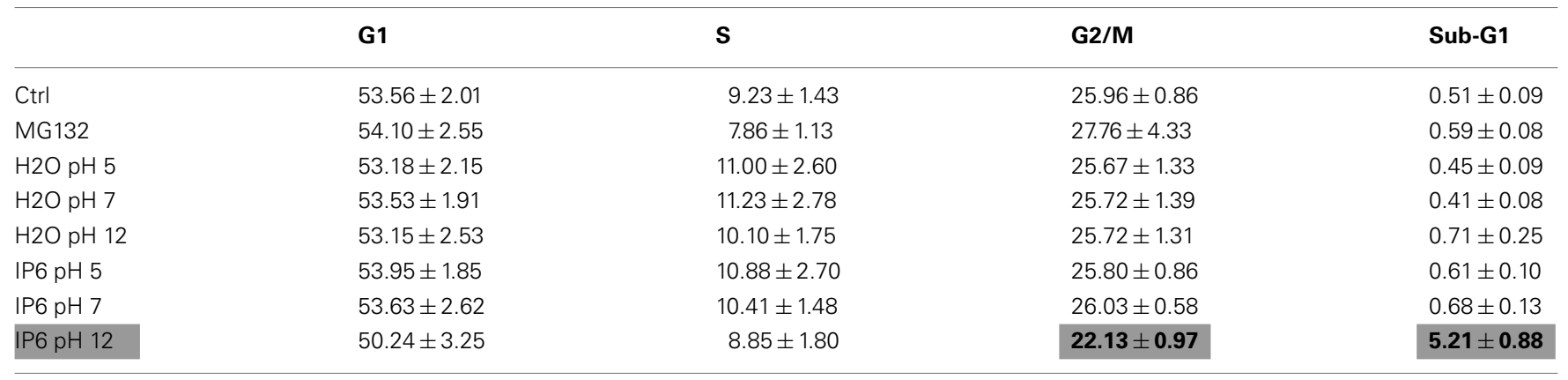

Results highlighted and in bold are statistically significantly different.

Compared to the corresponding water control.

${ }^{*}$ Cell percentage in each phase quantified by FACS following PI staining.

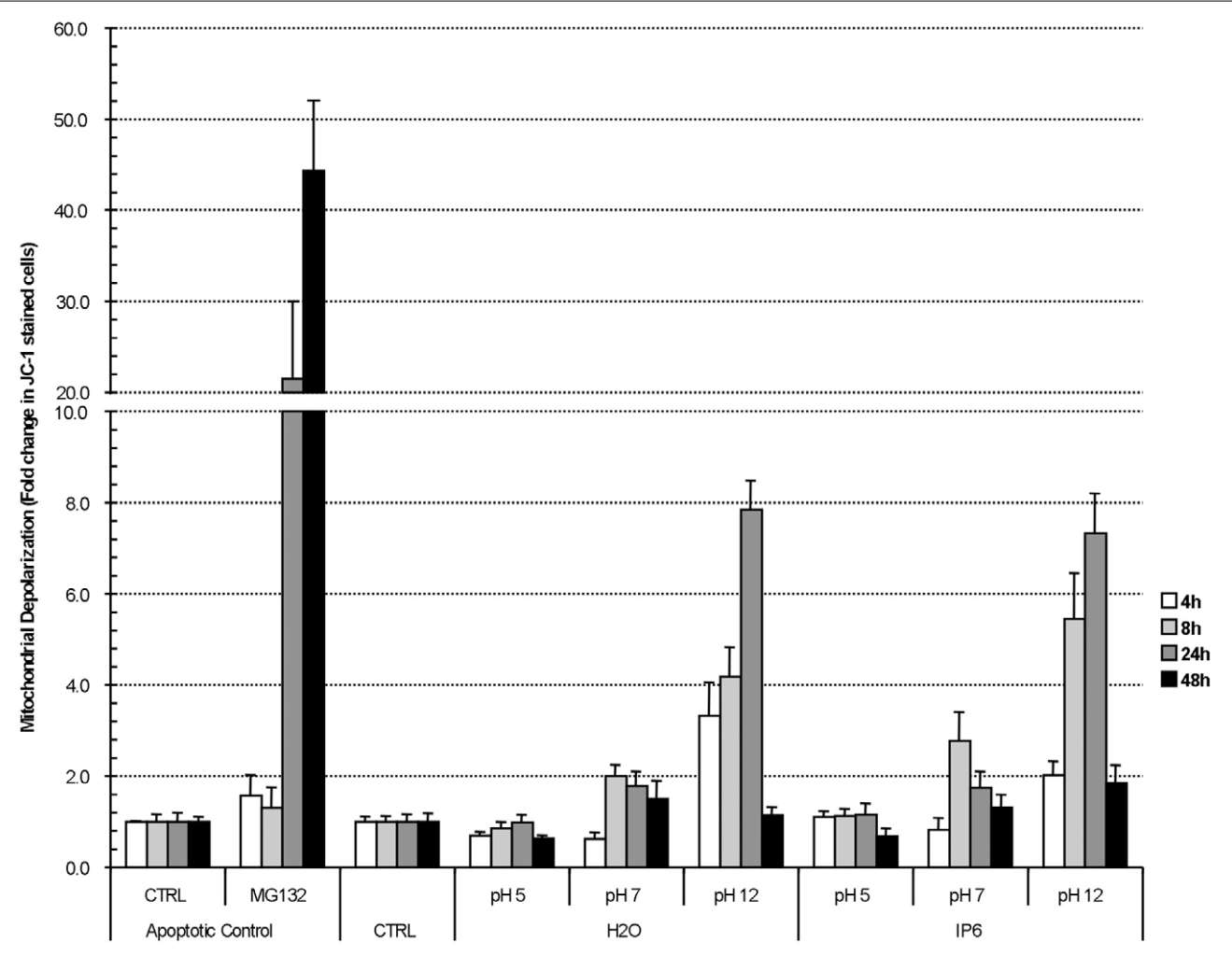

FIGURE 3 | IP6 does not impact mitochondrial depolarization. PC-3 cells were treated with either $2 \mathrm{mM} \mathrm{IP6}$ at $\mathrm{pH} 5, \mathrm{pH} 7$, or $\mathrm{pH} 12$ or the corresponding volumes of $\mathrm{H}_{2} \mathrm{O}$ at $\mathrm{pH} 5, \mathrm{pH}$, and $\mathrm{pH} 12$ for after 4, 8, 24, and $48 \mathrm{~h}$. In the last $15 \mathrm{~min}$ prior to analysis, cells were stained with JC-1 and mitochondrial depolarization was assessed by FACS. MG132 served as a control to induce cellular apoptosis. Data is represented as the relative fold change compared to non-treated control. Average of three experiments done in triplicate. Errors bars represent standard error of the mean. 
investigate mitochondrial depolarization or mitochondrial outer membrane permeation (MOMP), another event associate with apoptotic cell death. Similar to PARP cleavage (Kaufmann et al., 1993), mitochondrial depolarization is an early event of apoptosis, which is associated with the release of cytochrome $c$ (Heiskanen et al., 1999). Mitochondrial depolarization can be quantified by a shift from red to green following JC-1 staining. Our results illustrate that, compared to $\mathrm{H}_{2} \mathrm{O}$ controls, there was no statistically significant induction of mitochondrial depolarization by IP6 at the various $\mathrm{pH}$ studied (Figure 3). Together, these results suggest that IP6 promotes the accumulation of sub-G1 PC-3 cells and the reduced expression of PARP. However, this increase in sub-G1 cells was not associated with the appearance of cleaved-PARP or mitochondrial depolarization, two factors typically associated with an apoptotic cell death.

\section{IP6 AT pH 12 MODULATES INTRACELLULAR SIGNALIZATION}

Finally, we then evaluated whether the $\mathrm{pH}$ of the IP6 solution could differentially affect the phosphorylation status of intracellular effectors documented to be modulated by IP6. We detected a clear decrease in the phosphorylation status of AKT (S473) and PDK1 (S241) following treatment with IP6 at pH 12 (Figure 4A). Again, these variations were not observed with the IP6 at $\mathrm{pH} 5$ or at $\mathrm{pH} 7$. Conversely, we observed an induced expression of phospho-ERK (T202/Y204) with the IP6 at pH 12. The expression of phospho-ERK was also apparent following stimulation with IP6 at $\mathrm{pH} 7$, albeit to a smaller extent (Figure 4B). Overall, our results demonstrate that the $\mathrm{pH}$ of the IP6 solution directly influenced the IP6 actions on cellular metabolism, proliferation, and cell cycling, as well as intracellular signaling.

\section{DISCUSSION}

Numerous publications discuss the anti-cancer properties of IP6 in in vitro and in vivo prostate cancer models (reviewed in Vucenik and Shamsuddin, 2006). There are several cellular pathways affected by IP6 and the molecular machinery modulated following IP6 treatment is being further characterized. As IP6 is orally administered in vivo, the IP6 solution must accordingly be edible. However, when the often-used dodecasodium IP6 salt is reconstituted in aqueous solution, the resulting solution is at $\mathrm{pH}$ 12 , which is not fit for consumption. In this study, we questioned whether the $\mathrm{pH}$ of the ingested IP6 solution could influence the previously documented cytotoxic properties of IP6.

The results presented in this study confirmed that, compared to $\mathrm{pH}$-adjusted control $\mathrm{H}_{2} \mathrm{O}$ solutions, IP6 at any $\mathrm{pH}$ reduced the metabolic rate and the proliferation of hormone-refractory PC- 3 cells. However, it was the IP6 solutions at pH 5 and $\mathrm{pH}$ 12 that offered the most significant inhibitory potential on the metabolic rate of PC-3 cells and the IP6 at pH 12 that most significantly in vitro reduced cellular proliferation. Furthermore, when we investigated the phosphorylation status of key signaling molecules described to be regulated by IP6, we observed that, again, only the IP6 solution at $\mathrm{pH} 12$ diminished the phosphorylation of key signaling molecules. Comparatively, the IP6 at pH 5 and pH 7 did not modulate the phosphorylation of AKT or PDK1 and had a weak induction of phospho-ERK compared to IP6 at pH 12. These results contrast with recently published data showing a significant

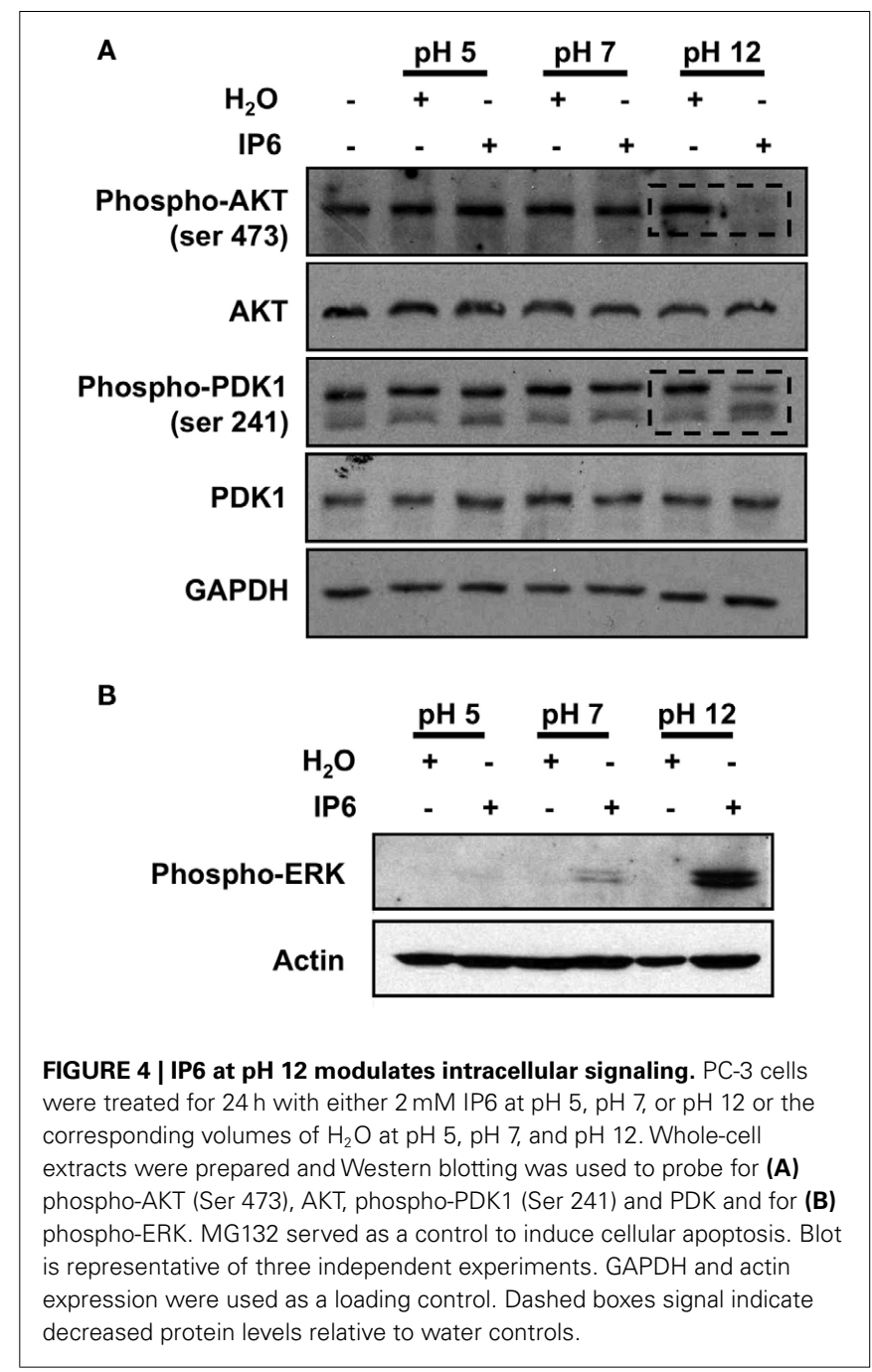

effect of IP6 buffered at $\mathrm{pH} 7.4$ on the proliferation of PC-3 cells as well as on the phosphorylation status of AKT and ERK (Gu et al., 2010). The impact of $\mathrm{pH}$ on the regulatory properties of IP6 on other signaling pathways should be further assessed as our results clearly illustrate the impact of $\mathrm{pH}$ on the IP6 properties.

The intriguing results observed in our study concerns accumulation of sub-G1 PC-3 cells following treatment with IP6 at $\mathrm{pH}$ 12. Whereas short-lived and low level MOMP is observed following treatment with both water $\mathrm{pH} 12$ and IP6 pH 12, only IP6 $\mathrm{pH} 12$ leads to increased cytotoxicity, acute sub-G1 cell accumulation, and reduced cell growth. We must therefore conclude that the MOMP observed in both cases is not linked with apoptosis but may instead be an artifact induced by basic $\mathrm{pH}$. The observation of sub-G1 cells only in the IP6 pH 12-treated cells (and not at neutral or acidic $\mathrm{pH}$ ) is nonetheless intriguing. To explain this phenomenon, we need to consider the fact that the $\mathrm{pI} /$ cell cycle assay sub-G1 peak actually measures cells in which DNA has been fragmented and lost from the cells due to the fixation procedure. While DNA fragmentation occurs at late stages of apoptosis (e.g., after $24 \mathrm{~h}$ with MG132) it can also occur following extensive DNA-damage via double-strand (DS) breaks. Note that the 
IP6 sub-G1 is maximal at $8 \mathrm{~h}$ then progressively decreases. This could suggest that DNA DS breaks are being induced by IP6 $\mathrm{pH}$ 12 early on then progressively repaired. We would further predict that such DS breaks would occur preferentially in the G2/M phase of the cell cycle, as the fraction of cells in this phase inversely correlates with the sub-G1 peak. This idea is particularly interesting considering that in the literature, endogenous IP6 normally found in cells (which should be at $\sim \mathrm{pH} 7$ as opposed to $\mathrm{pH} 12$ ) has been found to stimulate non-homologous end-joining (NHEJ) by binding $\mathrm{Ku} 70 / 80$. It is tempting to speculate that IP6 at $\mathrm{pH} 12$ inhibits rather that stimulates repair via NHEJ, leading to accumulation of DS breaks in cells undergoing G2/M transition. As the $\mathrm{pH} /$ ionic balance eventually re-equilibrates following IP6 $\mathrm{pH} 12$ treatment (see Figures A1A,B in Appendix), NHEJ repair would then resume leading to progressively fewer DS breaks an consequently fewer sub-G1 cells over time and resumed progression through G2/M or cell death through a non-apoptotic mechanism. However, since we also observe decreased growth rates in cells treated with IP6 pH 5 without accumulation of cells in sub-G1, more experiments are needed to precisely characterize how IP6 leads to reduced cell growth rates/and death in a $\mathrm{pH}$-dependent fashion.

One mechanism that has been proposed to mediate the chemopreventive abilities of IP6 activity is through its role as an antioxidant. The negatively charged phosphates in position 1, 2, and 3 constitute a unique (axial-equatorialaxial) conformation that confers anti-oxidant properties to IP6 by chelating $\mathrm{Fe}^{3+}$ and preventing $\mathrm{Fe}^{3+}$-catalyzed hydroxyl radical formation (Graf et al., 1987; Hawkins et al., 1993; Spiers et al., 1996). IP6-mediated chelation of other metals such as zinc, calcium, and magnesium has also been proposed to play a role due to the potential role of these divalent cations in cell proliferation (Thompson and Zhang, 1991; Jariwalla, 1999; Urbano et al., 2000). As we would expect that at $\mathrm{pH}$ 12 , the chelating potential of IP6 would be greater than at lower $\mathrm{pH}$ (because of an excess of free $\mathrm{H}+$ ions), perhaps basic conditions

\section{REFERENCES}

Agarwal, C., Dhanalakshmi, S., Singh, R. P., and Agarwal, R. (2004). Inositol hexaphosphate inhibits growth and induces g1 arrest and apoptotic death of androgendependent human prostate carcinoma lncap cells. Neoplasia 6, 646-659.

Diallo, J. S., Betton, B., Parent, N., Peant, B., Lessard, L., Le Page, C., Bertrand, R., Mes-Masson, A. M., and Saad, F. (2008). Enhanced killing of androgen-independent prostate cancer cells using inositol hexakisphosphate in combination with proteasome inhibitors. Br. J. Cancer 99, 1613-1622.

Diallo, J. S., Peant, B., Lessard, L., Delvoye, N., Le Page, C., MesMasson, A. M., and Saad, F. (2006). An androgen-independent androgen receptor function protects from inositol hexakisphosphate toxicity in the $\mathrm{pc} 3 / \mathrm{pc} 3(\mathrm{ar})$

favor metal chelating properties of IP6. Chelating properties of IP6, could also be expected to impact cellular processes such as calcium-mediated signaling and clathrin-mediated receptor endocytosis, which has been notably found to be inhibited by IP6 (Zi et al., 2000).

Since the $\mathrm{pH}$ can change drastically as the molecule travels through the gastro-intestinal tract, our findings have implications for in vivo use of IP6, which has largely been via oral routes thus far. In addition to the fact that $\mathrm{mM}$ concentrations of IP6 are required to elicit anti-cancer activity, this may argue for further evaluating the activity of basic-pH buffered IP6 formulations by intravenous injection. To this end, while the concentrations required for IP6mediated anti-tumor activity are certainly high, it should be noted that glucose, which is of similar chemical composition, is typically present in the blood at concentrations of $\sim 5 \mathrm{mM}$ (Lam et al., 2005). In addition, some clinically approved HDAC inhibitors, such as sodium butyrate and valproic acid for example, are also active in the $\mathrm{mM}$ range when used in vitro (Kuefer et al., 2004; Xia et al., 2006).

In conclusion, our work demonstrates that the $\mathrm{pH}$ of the IP6 solution must be taken in consideration when evaluating the anti-tumoral properties of this phytochemical. We demonstrate significant differences in the activity of IP6 depending on its $\mathrm{pH}$ on the metabolic activity, cell proliferation, and cell death of PC-3 cells.

\section{ACKNOWLEDGMENTS}

The authors would like to thank laboratory members for helpful discussions. We are grateful to Nathalie Delvoye for her technical support. This work is supported by the René Malo Initiative of the Institut du cancer de Montréal and the Fondation Sybila Hesse. Fred Saad holds the Université de Montréal Chair in Prostate Cancer Research. Philippe O. Gannon, Ismaël Hervé Koumakpayi, and Jean-Simon Diallo receive support from the Fonds de la Recherche en Santé du Québec and Defi Canderel.

A., and Irvine, R. F. (1993). Inhibition of iron-catalysed hydroxyl radical formation by inositol polyphosphates: a possible physiological function for myo-inositol hexakisphosphate. Biochem. J. 294(Pt 3), 929-934.

Heiskanen, K. M., Bhat, M. B., Wang, H. W., Ma, J., and Nieminen, A. L. (1999). Mitochondrial depolarization accompanies cytochrome c release during apoptosis in pc6 cells. J. Biol. Chem. 274, 5654-5658.

Jagadeesh, S., and Banerjee, P. P. (2006). Inositol hexaphosphate represses telomerase activity and translocates tert from the nucleus in mouse and human prostate cancer cells via the deactivation of akt and pkcalpha. Biochem. Biophys. Res. Commun. 349, 1361-1367.

Jariwalla, R. J. (1999). Inositol hexaphosphate (ip6) as an antineoplastic and lipid-lowering agent. Anticancer Res. 19, 3699-3702.
Jariwalla, R. J. (2001). Rice-bran products: phytonutrients with potential applications in preventive and clinical medicine. Drugs Exp. Clin. Res. 27, 17-26.

Kaufmann, S. H., Desnoyers, S., Ottaviano, Y., Davidson, N. E., and Poirier, G. G. (1993). Specific proteolytic cleavage of poly(adpribose) polymerase: an early marker of chemotherapy-induced apoptosis. Cancer Res. 53, 3976-3985.

Kuefer, R., Hofer, M. D., Altug, V., Zorn, C., Genze, F., Kunzi-Rapp, K., Hautmann, R. E., and Gschwend, J. E. (2004). Sodium butyrate and tributyrin induce in vivo growth inhibition and apoptosis in human prostate cancer. Br. J. Cancer 90, 535-541.

Lam, T. K., Gutierrez-Juarez, R., Pocai, A., and Rossetti, L. (2005). Regulation of blood glucose by hypothalamic pyruvate metabolism. Science 309, 943-947. 
Raina, K., Rajamanickam, S., Singh, R. P., and Agarwal, R. (2008). Chemopreventive efficacy of inositol hexaphosphate against prostate tumor growth and progression in tramp mice. Clin. Cancer Res. 14, 3177-3184.

Roy, S., Gu, M., Ramasamy, K., Singh, R. P., Agarwal, C., Siriwardana, S., Sclafani, R. A., and Agarwal, R. (2009). P21/cip1 and p27/kip1 are essential molecular targets of inositol hexaphosphate for its antitumor efficacy against prostate cancer. Cancer Res. 69, 1166-1173.

Shamsuddin, A. M., Vucenik, I., and Cole, K. E. (1997). Ip6: a novel anticancer agent. Life Sci. 61, 343-354.

Shamsuddin, A. M., and Yang, G. Y. (1995). Inositol hexaphosphate inhibits growth and induces differentiation of pc-3 human prostate cancer cells. Carcinogenesis 16, 1975-1979.

Singh, R. P., Agarwal, C., and Agarwal, R. (2003). Inositol hexaphosphate inhibits growth, and induces gl arrest and apoptotic death of prostate carcinoma dul45 cells: modulation of cdki-cdk-cyclin and prb-related protein-e2f complexes. Carcinogenesis 24, 555-563.

Singh, R. P., Sharma, G., Mallikarjuna, G. U., Dhanalakshmi, S., Agarwal, C., and Agarwal, R. (2004). In vivo suppression of hormonerefractory prostate cancer growth by inositol hexaphosphate: induction of insulin-like growth factor binding protein-3 and inhibition of vascular endothelial growth factor. Clin Cancer Res. 10(1 Pt 1), 244-250.

Spiers, I. D., Barker, C. J., Chung, S. K., Chang, Y. T., Freeman, S., Gardiner, J. M., Hirst, P. H., Lambert, P. A., Michell, R. H., Poyner, D. R., Schwalbe, C. H., Smith, A. W., and Solomons, K. R. (1996). Synthesis and iron binding studies of myo-inositol 1,2,3trisphosphate and $( \pm)$-myo-inositol 1,2-bisphosphate, and iron binding studies of all myo-inositol tetrakisphosphates. Carbohydr. Res. 282, 81-99.

Thompson, L. U., and Zhang, L. (1991). Phytic acid and minerals: effect on early markers of risk for mammary and colon carcinogenesis. Carcinogenesis 12, 2041-2045.
Urbano, G., Lopez-Jurado, M., Aranda, P., Vidal-Valverde, C., Tenorio, E. and Porres, J. (2000). The role of phytic acid in legumes: antinutrient or beneficial function? J. Physiol. Biochem. 56, 283-294.

Vucenik, I., and Shamsuddin, A. M (2003). Cancer inhibition by inositol hexaphosphate (ip6) and inositol: from laboratory to clinic. J. Nutr. 133(11 Suppl. 1), 3778S-3784S.

Vucenik, I., and Shamsuddin, A. M. (2006). Protection against cancer by dietary ip6 and inositol. Nutr. Cancer 55, 109-125.

Xia, Q., Sung, J., Chowdhury, W., Chen, C. L., Hoti, N., Shabbeer, S., Carducci, M., and Rodriguez, R. (2006). Chronic administration of valproic acid inhibits prostate cancer cell growth in vitro and in vivo. Cancer Res. 66, 7237-7244.

Zi, X., Singh, R. P., and Agarwal, R. (2000). Impairment of erbbl receptor and fluid-phase endocytosis and associated mitogenic signaling by inositol hexaphosphate in human prostate carcinoma du 145 cells. Carcinogenesis 21 , 2225-2235.
Conflict of Interest Statement: The authors declare that the research was conducted in the absence of any commercial or financial relationships that could be construed as a potential conflict of interest.

Received: 12 July 2011; accepted: 04 October 2011; published online: 31 October 2011.

Citation: Betton B, Gannon PO, Koumakpayi IH, Diallo J-S, MesMasson A-M and Saad F (2011) Influence of $\mathrm{pH}$ on the cytotoxic activity of inositol hexakisphosphate (IP6) in prostate cancer. Front. Oncol. 1:40. doi: 10.3389/fonc.2011.00040

This article was submitted to Frontiers in Molecular and Cellular Oncology, a specialty of Frontiers in Oncology.

Copyright (c) 2011 Betton, Gannon, Koumakpayi, Diallo, Mes-Masson and Saad. This is an open-access article subject to a non-exclusive license between the authors and Frontiers Media SA, which permits use, distribution and reproduction in other forums, provided the original authors and source are credited and other Frontiers conditions are complied with. 


\section{APPENDIX}

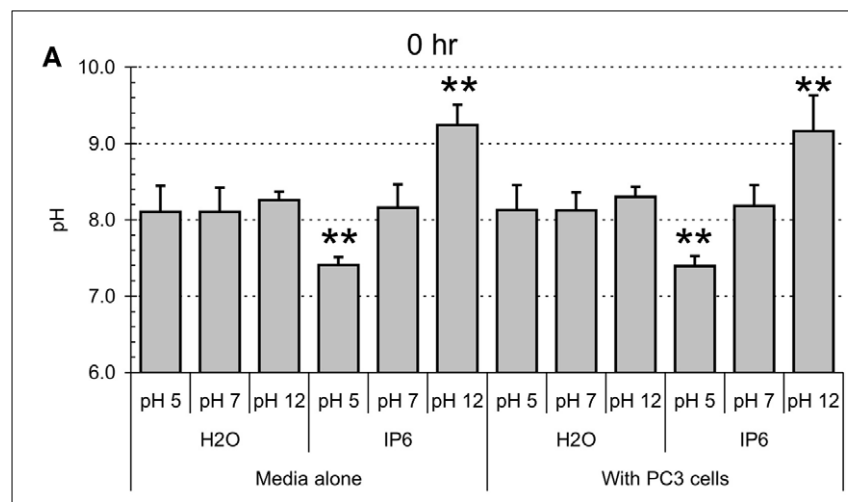

B

$24 \mathrm{hrs}$

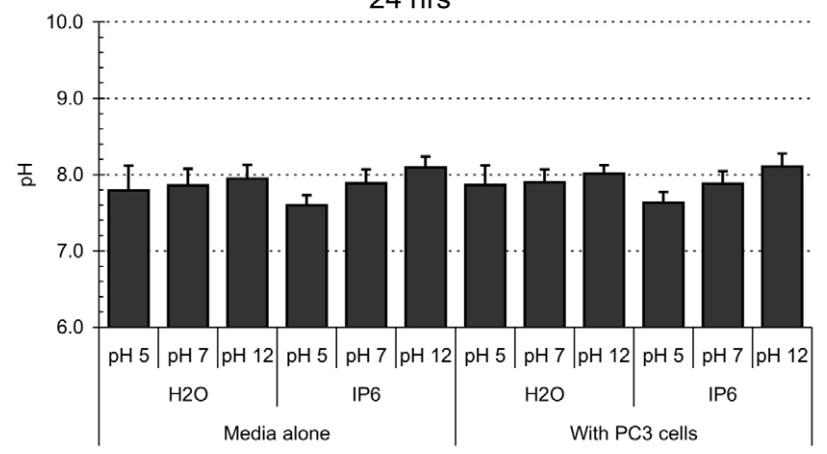

FIGURE A1 | pH variations of the culture media after IP6 or water treatment. PC-3 cells were plated at 200,000 cells $/ \mathrm{ml}$ in 6-well plates in a final volume of $3 \mathrm{ml}$ of medium/well. The culture media consists in RPMl 1640 complemented with $10 \% \mathrm{FCS}$, gentamicin $(50 \mu \mathrm{g} / \mathrm{ml})$, and amphotericin B $(250 \mathrm{ng} / \mathrm{ml}$; Gibco, Carlsbad, CA, USA). PC-3 cells were treated with either $2 \mathrm{mM} \mathrm{IP6}$ at $\mathrm{pH} 5, \mathrm{pH} 7$, or $\mathrm{pH} 12$ or the corresponding volumes of $\mathrm{H}_{2} \mathrm{O}$ at $\mathrm{pH} 5, \mathrm{pH} 7$, and $\mathrm{pH}$ 12. In parallel, culture media without PC-3 cells were supplemented with similar volumes of $2 \mathrm{mM} \mathrm{IP6}$ or $\mathrm{H}_{2} \mathrm{O}$. The $\mathrm{pH}$ was measured immediately after stimulation $[0 \mathrm{~h},(\mathbf{A})]$ or after $24 \mathrm{~h}$ (B) of treatment using a pH-meter (Corning $\mathrm{pH}$ meter 340, Corning, NY, USA). Data represents average of three experiments. Errors bars represent SD.

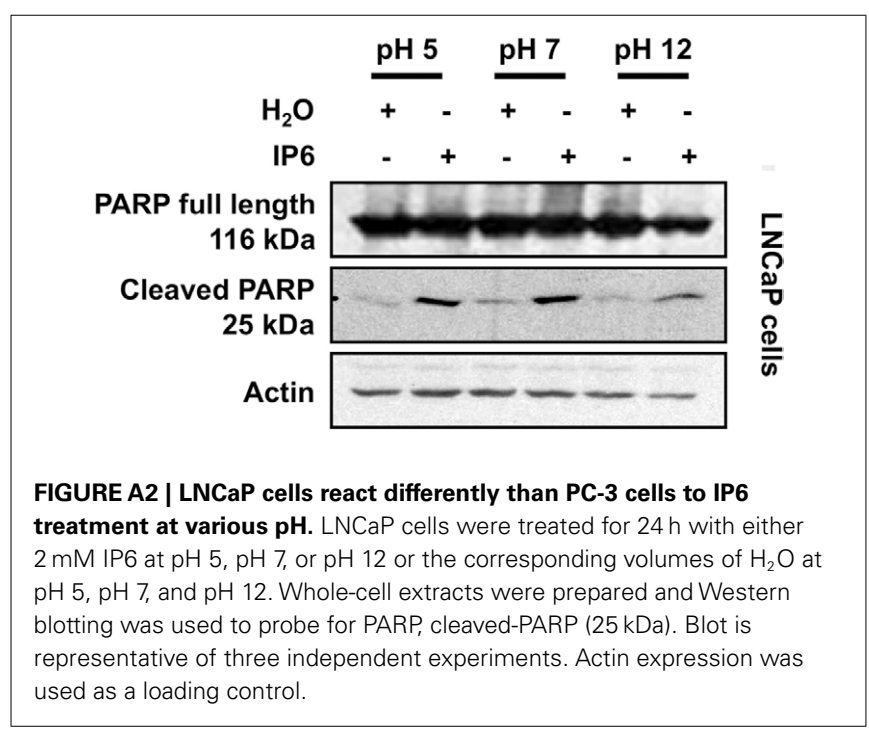




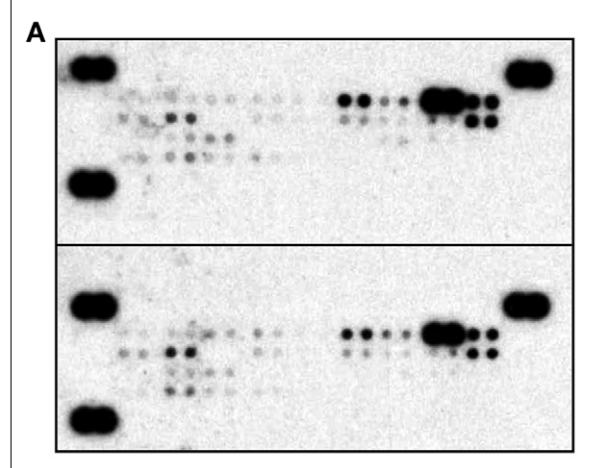

Top panel: $\mathrm{H}_{2} \mathrm{O} \mathrm{pH} 5$

Bottom panel: IP6 pH 5

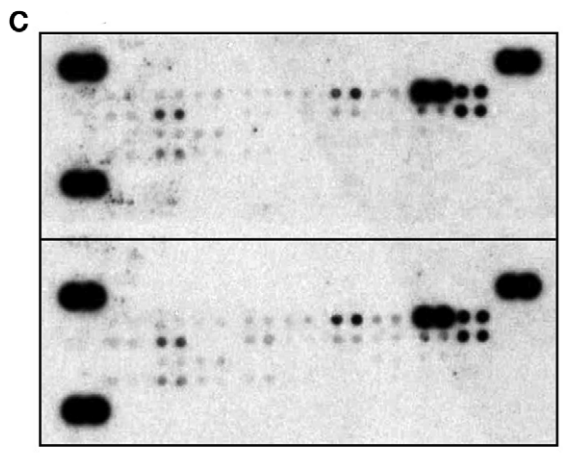

Top panel: $\mathrm{H}_{2} \mathrm{O} \mathrm{pH} 7$

Bottom panel: IP6 pH 7

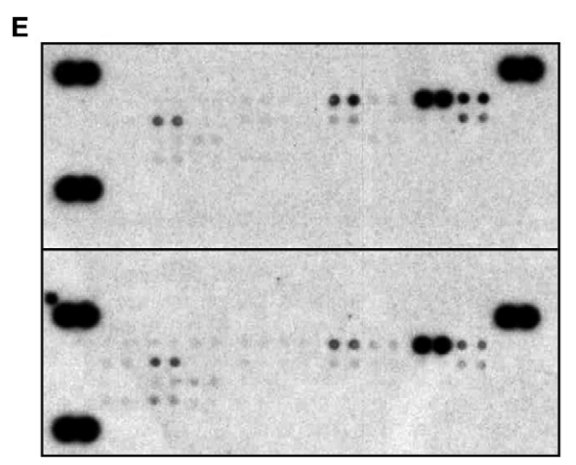

Top panel: $\mathrm{H}_{2} \mathrm{O} \mathrm{pH} 12$ Bottom panel: IP6 pH 12
B

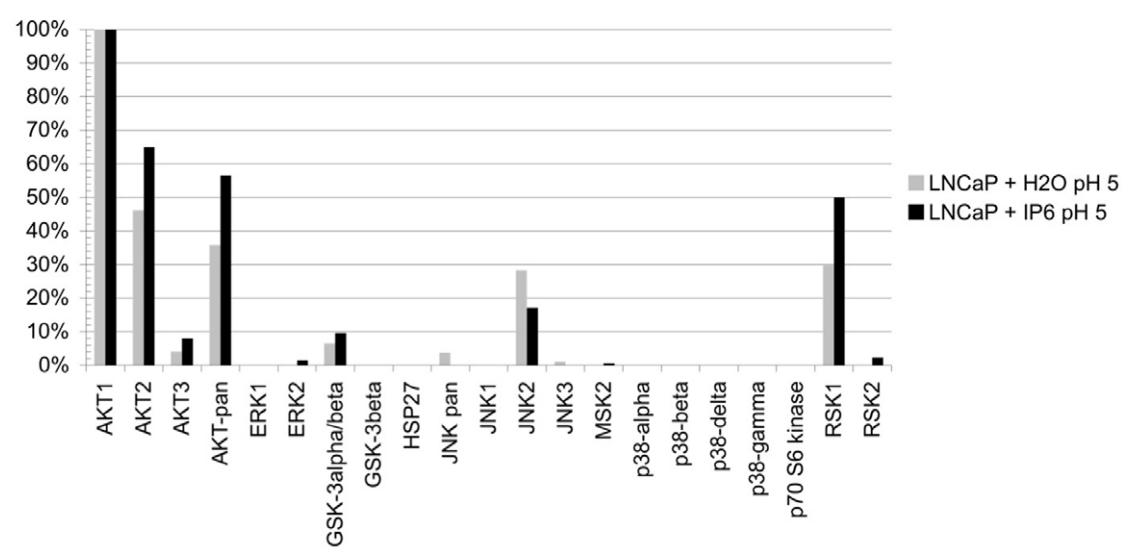

D

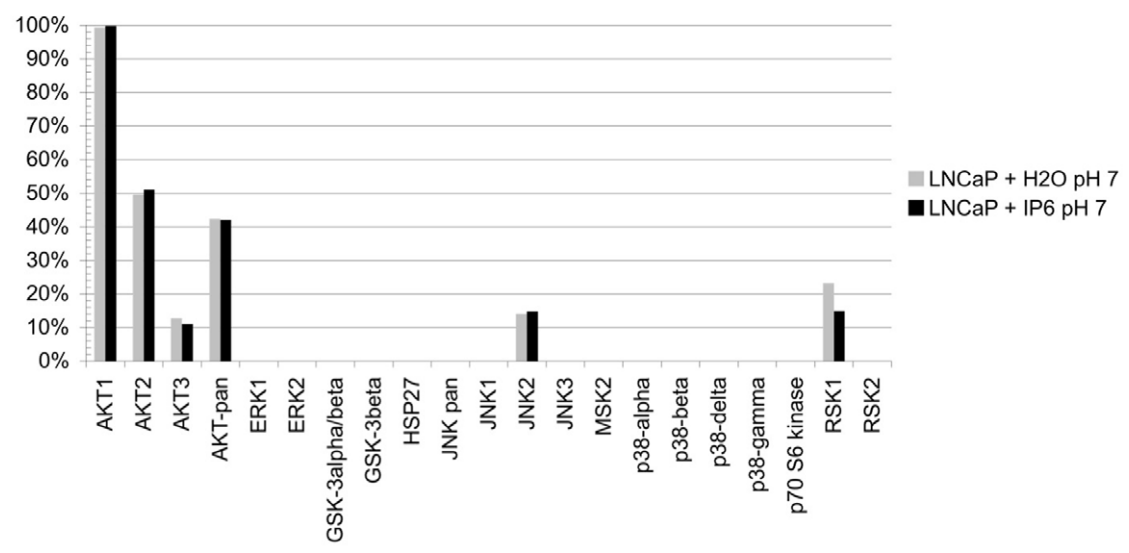

$\mathbf{F}$

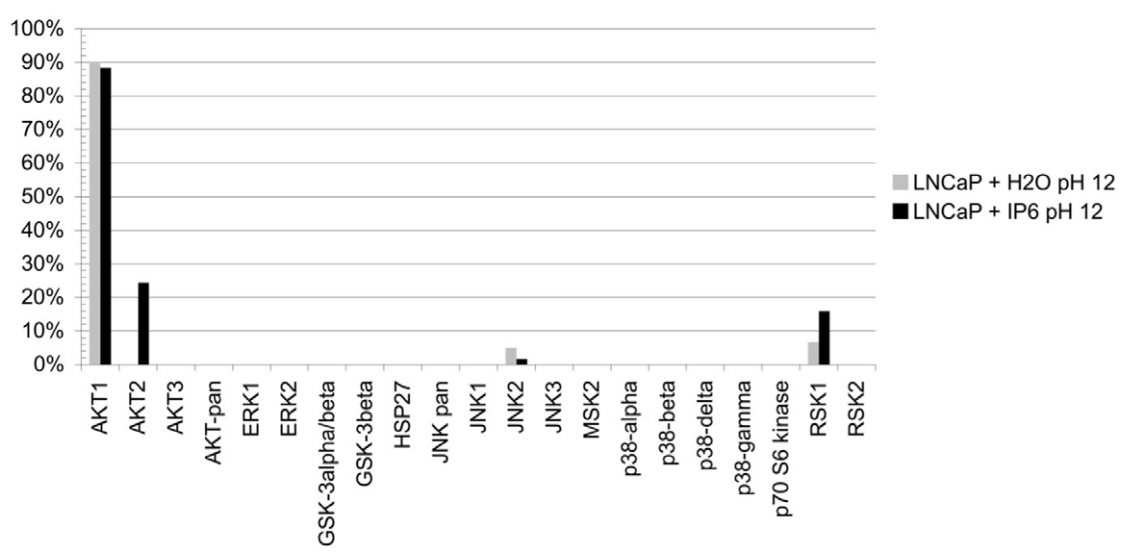

FIGURE A3 | Phosphorylation status of several kinases in LNCaP cells following IP6 treatment using Proteome Profiler membranes. $L N C a P$ cells were treated for $24 \mathrm{~h}$ with either $2 \mathrm{mM} \mathrm{IP6}$ at pH 5, pH 7, or pH 12 or the corresponding volumes of $\mathrm{H}_{2} \mathrm{O}$ at $\mathrm{pH} 5, \mathrm{pH} 7$, and $\mathrm{pH} 12$. Whole-cell extracts were prepared according to the manufacturer's protocol and hybridized to the proteome profiler membranes (RnD Systems). Densitometry was performed with the Quantity One software (BioRad) using the positive control dots (top left, bottom left, and top right corners) in the qualitative expression ratio. Protein profiler membranes and corresponding densitometry for: (A,B) pH 5, (C,D) pH 7, (E,F) pH 12. Note that the signal was relatively similar for the three conditions $(\mathrm{pH} 5, \mathrm{pH} 7$, and $\mathrm{pH}$ 12) with few kinase phosphorylations detected. However, we did observe an increase in the phosphorylation of AKT2 with the IP6 pH 12 treatment. 
Table A1 | Cell cycle distribution* following IP6 treatment.

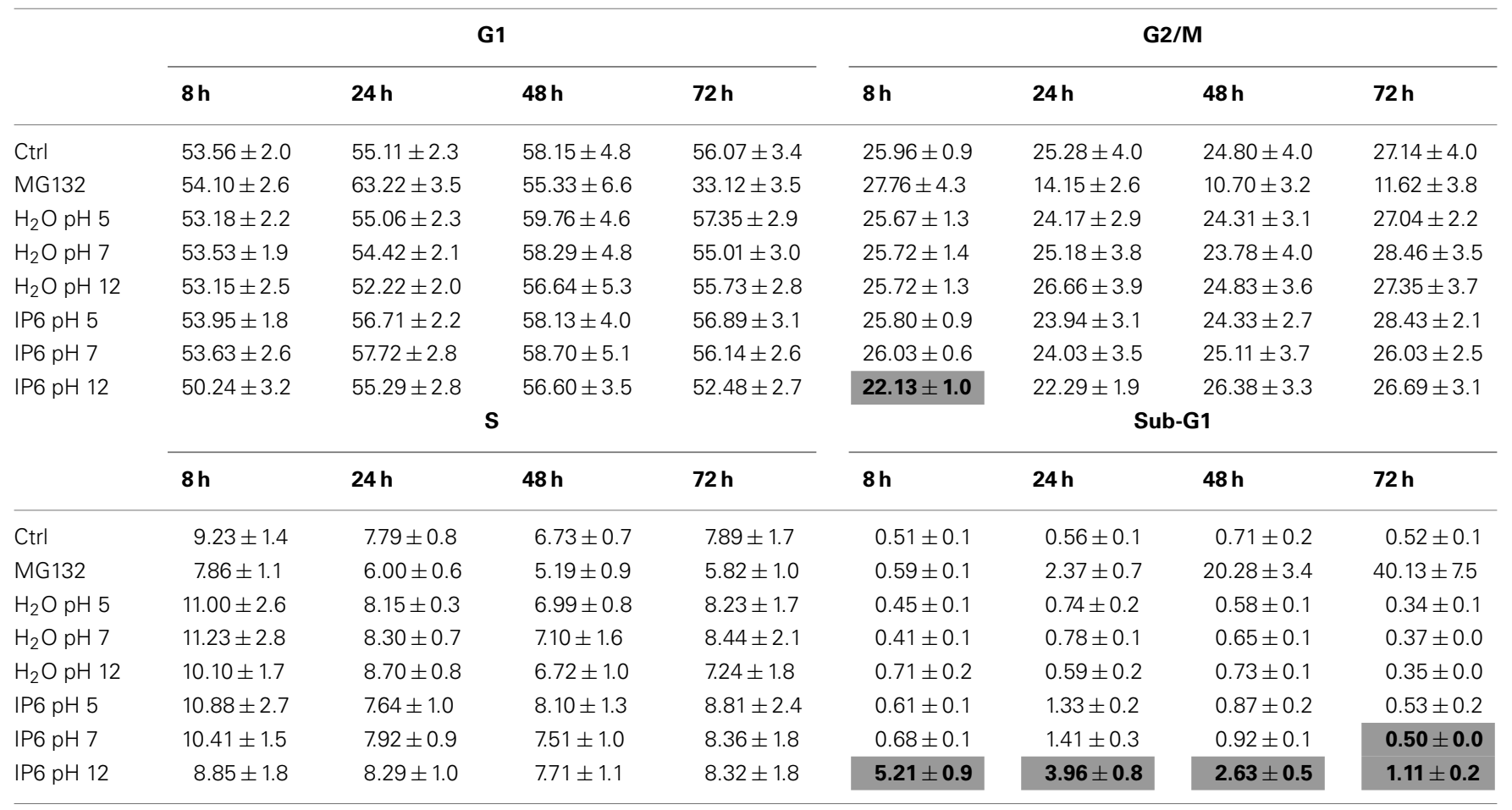

Results highlighted and in bold are statistically significantly different compared to the corresponding water control.

${ }^{*}$ Cell percentage in each phase quantified by FACS following PI staining. 